INVITED REVIEW

\title{
GOLD PHOSPHIDE COMPLEXES
}

\section{EDUARDO J. FERNÁNDEZ ${ }^{a}$, ANTONIO LAGUNA ${ }^{b}$ AND M. ELENA OLMOS ${ }^{a}$}

[a] Departamento de Química. Universidad de la Rioja. Grupo de Síntesis Química de La Rioja, UA-CSIC. Complejo Científico Tecnológico 26001 Logroño (Spain).

[b] Departamento de Química Inorgánica. Instituto de Ciencia de Materiales de Aragón, Universidad de Zaragoza-CSIC. 50009 Zaragoza (Spain). (Received $4^{\text {th }}$ April 2007 - Accepted $18^{\text {th }}$ June 2007)

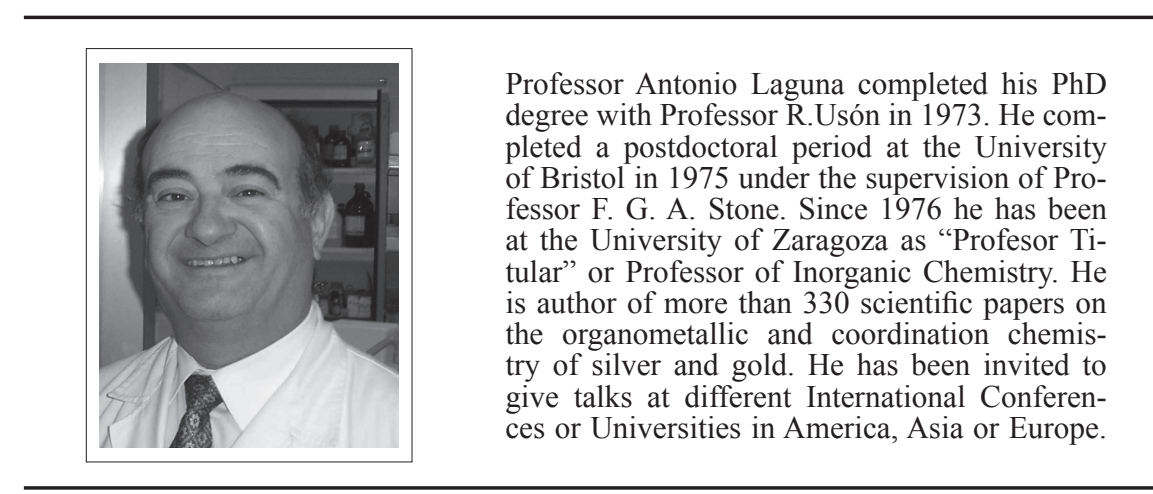

\section{INTRODUCTION}

The vast majority of gold complexes with five group-element donor ligands contain tertiary phosphines, although compounds with amine, arsine or stibine ligands are also known. Although phosphide ligands, which are formed by deprotonation of non-tertiary phosphines, are closely related to the former, they have been employed to a lesser extent, mainly due to their lower stability. Thus, the chemistry of phosphido-bridged derivatives of the main group elements ${ }^{1-3}$ or transition metals ${ }^{4-6}$ has been a matter of interest for various research groups in the last few years. While there are many phosphido complexes with metals, mainly of groups $6^{7-12}$ or $10,^{13-20}$ the chemistry of gold derivatives has experienced less progress in this field of research in spite of the possible catalytic behaviour of di- and polynuclear phosphido-bridged compounds. ${ }^{21}$ This is an interesting field of research, because the substitution of one or more protons by metal atoms allows the synthesis of homo- or heteropolynuclear compounds in which the presence of a small bridging atom, such as phosphorus, may give rise to intermetallic contacts, which, as is known, are often responsible for surprising and interesting optical properties, such as luminescence, area with an increasing importance in the last years. This review focuses on gold phospide complexes derived from secondary phosphines $\left(\mathrm{PR}_{2} \mathrm{H}\right)$, primary phosphines $\left(\mathrm{PRH}_{2}\right)$, primary diphosphines $\left(\mathrm{PH}_{2}\left(\mathrm{CH}_{2}\right) \mathrm{PH}_{2}\right)$ or from $\mathrm{PH}_{3}$. The moieties derived from all these complexes usually act as bridging ligands between more than one gold centre or between gold and other transition metal centres.

\section{Secondary phosphine derivatives}

Different gold(I) polymers of formula $\left[\mathrm{AuPR}_{2}\right]_{\mathrm{n}}\left(\mathrm{R}=\mathrm{Ph}, p-\mathrm{C}_{6} \mathrm{H}_{4} \mathrm{Me}\right.$, $\left.p-\mathrm{C}_{6} \mathrm{H}_{4}{ }^{ } \mathrm{Bu}, \mathrm{Et}, \mathrm{C}_{8} \mathrm{H}_{17}\right)$ have been prepared by reaction of the corresponding secondary phosphine with different gold(I) compounds, such as [AuCl(tht)] (tht $=$ tetrahydrothiophene $^{22}$ or $[\mathrm{AuCl}(\mathrm{tdg})](\mathrm{tdg}=\text { thiodiglycol })^{23}$ in the presence of bases, or with $[\mathrm{AuMe}(\mathrm{PMe}, \mathrm{Ph})],{ }^{24}\left[\mathrm{Au}(\mathrm{acac})_{2}{ }^{-}(\mathrm{acac}=\right.$ acetylacetonate $) .{ }^{25}$ Although their solid state structures are not known, the use of bulkier substituents has recently enabled the determination of the oligomeric structures of some similar derivatives prepared by reaction of $\left[\mathrm{AuCl}\left(\mathrm{PHR}_{2}\right)\right]\left(\mathrm{PR}_{2}=\right.$ $\mathrm{PMes}_{2}, \mathrm{PCy}_{2}, \mathrm{P}^{\mathrm{B}} \mathrm{Bu}_{2}, \mathrm{PIs}_{2}$, PPhMes; Mes $=2,4,6-\mathrm{C}_{6} \mathrm{H}_{2} \mathrm{Me}_{3}, \mathrm{Cy}=$ cyclo- $\mathrm{C}_{6} \mathrm{H}_{11}$, Is $=2,4,6-\mathrm{C}_{6} \mathrm{H}_{2}{ }^{i} \mathrm{Pr}_{3}$ ) with aqueous ammonia. ${ }^{26}$ Although ${ }^{31} \mathrm{P}$ NMR spectroscopy showed that these complexes exist in solution as mixtures, presumably oligomeric rings of different sizes, X-ray diffraction studies of four of them revealed rings of varying size- $(\mathrm{n}=3,4,6)$ and conformations with alternating gold and phosphorus atoms. The $\mathrm{Au}-\mathrm{Au}$ distances in all the cases are too long to consider any bonding interaction between the metal centres.

The reaction of some of these compounds with $\mathrm{Q}\left[\mathrm{AuX} \mathrm{X}_{2}\right]\left(\mathrm{Q}=\mathrm{N}\left(\mathrm{PPh}_{3}\right)_{2}\right.$,
$\mathrm{NBu}_{4} ; \mathrm{X}=\mathrm{Cl}, \mathrm{Br}$, I) give dinuclear complexes of formula $\mathrm{Q}\left[(\mathrm{AuX})_{2}(\mu-\right.$ $\left.\left.\mathrm{PR}_{2}\right)\right]^{22,23,266,27}$ (Eqn. 1). Three of them - $\mathrm{NBu}_{4}\left[(\mathrm{AuBr})_{2}\left(\mu-\mathrm{PPh}_{2}\right)\right]^{27}$ and $\mathrm{PPN}\left[(\mathrm{AuCl})_{2}\left(\mu-\mathrm{PR}_{2}\right)\right]\left(\mathrm{PPN}=\mathrm{N}\left(\mathrm{PPh}_{3}\right)_{2} ; \mathrm{R}=\mathrm{Cy},{ }^{,} \mathrm{Bu}\right)^{266}$ - have been structurally characterized, showing almost linear X-Au-P angles, tetrahedral phosphorus and nonbonding $\mathrm{Au}-\mathrm{Au}$ distances (the shortest of them being $3.616 \AA$ ).

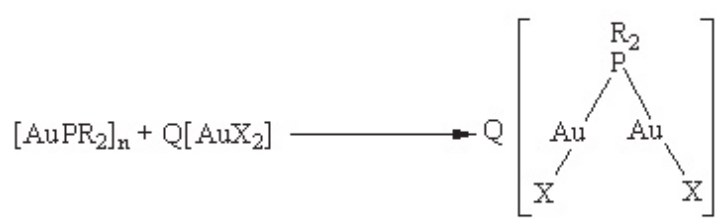

Eqn. 1

Although there are fewer examples of gold(III) complexes, one of the first gold phosphides described was the dinuclear gold(III) derivative $\left[\mathrm{Au}_{2} \mathrm{Me}_{4}(\mu\right.$ $\left.\left.\mathrm{PPh}_{2}\right)_{2}\right]$, which was obtained in 1976 by reaction of $\left[\mathrm{AuMe}_{3}\left(\mathrm{PPhMe}_{2}\right)\right]$ with $\mathrm{PPh}_{2} \mathrm{H}$, leading to the displacement of $\mathrm{PPhMe}{ }_{2}{ }^{24}$ The related pentafluorophenyl complex $\left[\mathrm{Au}_{2}\left(\mathrm{C}_{6} \mathrm{~F}_{5}\right)_{4}\left(\mu-\mathrm{PPh}_{2}\right)_{2}\right]$ has been more recently synthesized starting from $\left[\mathrm{Au}_{2}\left(\mathrm{C}_{6} \mathrm{~F}_{5}\right)_{4}(\mu-\mathrm{Cl})_{2}\right]$ (figure 1a) and $\mathrm{PPh}_{2} \mathrm{H}^{28}$ and it was structurally characterised, displaying two bridging diphenylphosphide groups between the square-planar gold(III) centers forming a four-membered ring. Even a dinuclear anionic gold(III) complex with only one phosphorus bridging atom, $\mathrm{NBu}_{4}\left[\left\{\mathrm{Au}\left(\mathrm{C}_{6} \mathrm{~F}_{5}\right)_{3}\right\}_{2}\left(\mu-\mathrm{PPh}_{2}\right)\right]$ (figure $1 \mathrm{~b}$ ), has been isolated, probably thanks to the stabilizing effect of the perfluorophenyl groups. ${ }^{28} \mathrm{As}$ in the gold(I) species, none of them show intermetallic contacts.

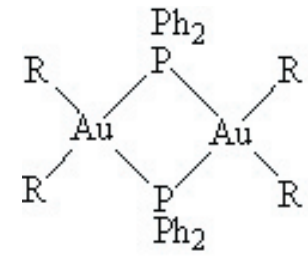

(a)

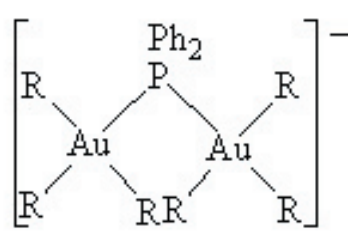

(b)
Figure 1 
This stabilizing effect has led to the development of a new area of research in this field: the chemistry of $\mathrm{Au}^{\mathrm{III}}$ and mixed $\mathrm{Au}^{\mathrm{III}} / \mathrm{M}^{\mathrm{I}}(\mathrm{M}=\mathrm{Cu}, \mathrm{Ag}$, $\mathrm{Au}$ ) phosphides, which has yielded a number of successful results in the last years. Thus, the diphenylphosphine complexes $\left[\mathrm{Au}\left(\mathrm{C}_{6} \mathrm{~F}_{5}\right)_{3}\left(\mathrm{PPh}_{2} \mathrm{H}\right)\right]$ and trans$\left[\mathrm{Au}\left(\mathrm{C}_{6} \mathrm{~F}_{5}\right)_{2}\left(\mathrm{PPh}_{2} \mathrm{H}\right)_{2}\right] \mathrm{ClO}_{4}$ have been shown as good precursors for this type of compounds, and their treatment with suitable coinage metal precursors in different molar ratios and in the presence of acetylacetonate as deprotonating agent leads to the synthesis of complexes of different nuclearity and charge, as well as with different number of diphenylphosphido bridging ligands. ${ }^{29-31}$

The dinuclear neutral or anionic products $\left[\mathrm{Au}\left(\mathrm{C}_{6} \mathrm{~F}_{5}\right)_{3}\left(\mu-\mathrm{PPh}_{2}\right) \mathrm{M}\left(\mathrm{PPh}_{3}\right)\right]$ $(\mathrm{M}=\mathrm{Ag}, \mathrm{Au})$ or $\mathrm{NBu}_{4}\left[\mathrm{Au}\left(\mathrm{C}_{6} \mathrm{~F}_{5}\right)_{3}\left(\mu-\mathrm{PPh}_{2}\right) \mathrm{Au}\left(\mathrm{C}_{6} \mathrm{~F}_{5}\right)\right]$ were thus obtained by reaction of equimolecular amounts of $\left[\mathrm{Au}\left(\mathrm{C}_{6} \mathrm{~F}_{5}\right)_{3}\left(\mathrm{PPh}_{2} \mathrm{H}\right)\right]$ and $\left[\mathrm{M}(\mathrm{acac})\left(\mathrm{PPh}_{3}\right)\right]$ or $\left[\mathrm{Au}\left(\mathrm{C}_{6} \mathrm{~F}_{5}\right)(\right.$ tht $\left.)\right]$ and $\mathrm{NBu}_{4}(\mathrm{acac})$, respectively. The trinuclear compounds $\operatorname{PPN}\left[\left\{\mathrm{Au}\left(\mathrm{C}_{6} \mathrm{~F}_{5}\right)_{3}\left(\mu-\mathrm{PPh}_{2}\right)\right\}_{2} \mathrm{M}\right] \quad(\mathrm{M}=\mathrm{Cu}, \mathrm{Ag}, \mathrm{Au})$, also obtained from $\left[\mathrm{Au}\left(\mathrm{CF}_{\mathrm{F}}\right)_{3}(\mathrm{PPh} \mathrm{H})\right]$, contain perfectly linear $\mathrm{M}^{\mathrm{I}}$ centers bonded to two phosphido gold(III) fragments. The X-ray crystal structure determinations were carried out for the silver(I) and gold(I) species, allowing us to compare their covalent radii, indicating that gold is smaller than silver in $0.07 \AA$, confirming the results obtained by Schmidbaur, who compared bond lengths in $\left[\mathrm{M}\left(\mathrm{PMes}_{3}\right)_{2}\right] \mathrm{BF}_{4}(\mathrm{M}=\mathrm{Au}, \mathrm{Ag}){ }^{32}$ An alternative strategy for the synthesis of some of them involves the use of $\left[\mathrm{Au}\left(\mathrm{C}_{6} \mathrm{~F}_{5}\right)_{3}(\mathrm{acac})\right]^{-}$as gold(III) precursor, as shown in scheme 1 .

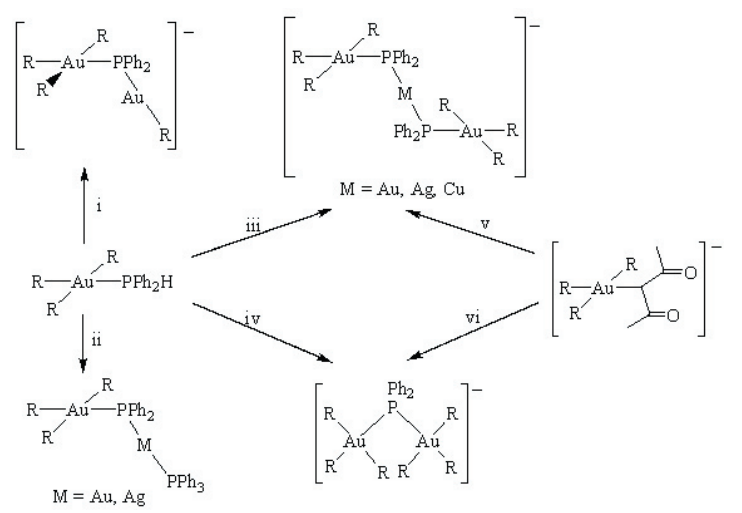

Scheme 1. $\mathrm{R}=\mathrm{C}_{6} \mathrm{~F}_{5}$; i) $[\mathrm{AuR}($ tht $)]+\mathrm{NBu}_{4}(\mathrm{acac})$; ii) $\left[\mathrm{Au}(\mathrm{acac})\left(\mathrm{PPh}_{3}\right)\right]$ or $\left[\mathrm{Ag}(\mathrm{TfO})\left(\mathrm{PPh}_{3}\right)\right]+\mathrm{NBu}_{4}$ (acac); iii) $1 / 2 \mathrm{PPN}\left[\mathrm{Au}(\mathrm{acac})_{2}\right], 1 / 2 \mathrm{AgClO}_{4}+\mathrm{PPN}($ acac $)$ or $1 / 2\left[\mathrm{Cu}(\mathrm{NCMe})_{4}\right] \mathrm{TfO}+\mathrm{PPN}(\mathrm{acac})$; iv) $\left[\mathrm{AuR}_{3}(\right.$ tht $\left.)\right]+\mathrm{NBu}_{4}$ (acac); v) $1 / 2$ $\left.\left[\mathrm{Au}\left(\mathrm{PPh}_{2} \mathrm{H}\right)_{2}\right] \mathrm{TfO} ; \mathrm{vi}\right)\left[\mathrm{AuR}_{3}\left(\mathrm{PPh}_{2} \mathrm{H}\right)\right]$

Similarly, starting from trans- $\left[\mathrm{Au}\left(\mathrm{C}_{6} \mathrm{~F}_{5}\right)_{2}\left(\mathrm{PPh}_{2} \mathrm{H}\right)_{2}\right] \mathrm{ClO}_{4}$, the trinuclear derivatives trans- $\mathrm{NBu}_{4}\left[\mathrm{Au}\left(\mathrm{C}_{6} \mathrm{~F}_{5}\right)_{2}\left\{\left(\mu-\mathrm{PPh}_{2}\right) \mathrm{Au}\left(\mathrm{C}_{6} \mathrm{~F}_{5}\right)\right\}_{2}\right]$, cis- $\left[\mathrm{Au}\left(\mathrm{C}_{6} \mathrm{~F}_{5}\right)_{2}\{(\mu-\right.$ $\left.\left.\left.\mathrm{PPh}_{2}\right) \mathrm{Au}\left(\mathrm{PPh}_{3}\right)\right\}_{2}\right] \mathrm{ClO}_{4}$ or PPN $\left[\left\{\mathrm{Au}\left(\mathrm{C}_{6} \mathrm{~F}_{5}\right)_{2}\left(\mu-\mathrm{PPh}_{2}\right)_{2}\right\}_{2} \mathrm{Cu}\right]$, which contain two (the first two) or four (the latter) phosphido bridging ligands, have been obtained. ${ }^{30} \mathrm{~A}$ series of tetranuclear neutral complexes $\left[\mathrm{Au}\left(\mathrm{C}_{6} \mathrm{~F}_{5}\right)_{2}\left(\mu-\mathrm{PPh}_{2}\right)_{2} \mathrm{M}\right]_{2}$ $(\mathrm{M}=\mathrm{Cu}, \mathrm{Ag}, \mathrm{Au})$ can also be isolated by reaction of the same gold(III) starting material with $\mathrm{M}(\mathrm{I})$ salts in the presence of acetylacetonate as deprotonating agent (2:1), as shown in scheme 2 .

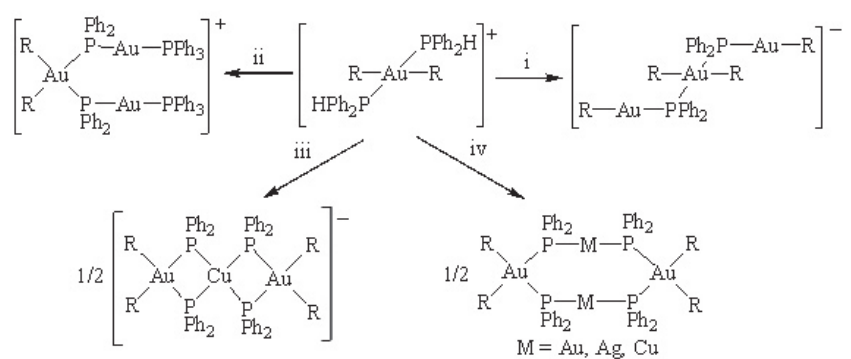

Scheme 2. $\mathrm{R}=\mathrm{C}_{6} \mathrm{~F}_{5} ;$ i) $2[\mathrm{AuR}($ tht $)]+2 \mathrm{NBu}_{4}(\mathrm{acac})$; ii) $2\left[\mathrm{Au}(\mathrm{acac})\left(\mathrm{PPh}_{3}\right)\right]$; iii) $1 / 2\left[\mathrm{Cu}(\mathrm{NCMe})_{4}\right] \mathrm{TfO}+2 \mathrm{PPN}(\mathrm{acac})$; iv) PPN $\left[\mathrm{Au}(\mathrm{acac})_{2}\right], \mathrm{Ag}\left(\mathrm{OClO}_{3}\right)+2$ $\mathrm{PPN}(\mathrm{acac})$ or $\left[\mathrm{Cu}(\mathrm{NCMe})_{4}\right] \mathrm{TfO}+2 \mathrm{PPN}(\mathrm{acac})$.

Furthermore, reaction of the mixed $\mathrm{Au}^{\mathrm{III}} / \mathrm{Ag}^{\mathrm{I}}$ diphenylphosphide complex $\left[\mathrm{Au}\left(\mathrm{C}_{6} \mathrm{~F}_{5}\right)_{2}\left(\mu-\mathrm{PPh}_{2}\right)_{2} \mathrm{Ag}\right]_{2}$ with an equimolecular amount of $\left[\mathrm{AgCl}\left(\mathrm{PPh}_{3}\right)\right]$ leads to the formal insertion of the latter into the starting complex, yielding the pentanuclear derivative $\left[\left\{\mathrm{Au}\left(\mathrm{C}_{6} \mathrm{~F}_{5}\right)_{2}\left\{\left(\mu-\mathrm{PPh}_{2}\right) \mathrm{AgPPh}_{3}\right\}\left(\mu-\mathrm{PPh}_{2}\right)\right\}_{2}(\mu-\mathrm{Ag})\left(\mu_{3}-\right.\right.$ $\mathrm{Cl})$. This compound displays an unusual perfectly planar T-frame $\mu_{3}-\mathrm{Cl}$ bridging the three silver atoms (see Figure 2). Surprisingly, this compound is also obtained by treatment of trans- $\left[\mathrm{Au}\left(\mathrm{C}_{6} \mathrm{~F}_{5}\right)_{2}\left(\mathrm{PPh}_{2} \mathrm{H}\right)_{2}\right] \mathrm{ClO}_{4}$ with $\left[\mathrm{Ag}(\mathrm{TfO})\left(\mathrm{PPh}_{3}\right)\right](\mathrm{TfO}=$ trifluoromethylsulphonate $)$ and $\mathrm{AgTfO}(2: 2: 1)$ in the presence of PPN(acac) and PPNCl. ${ }^{31}$

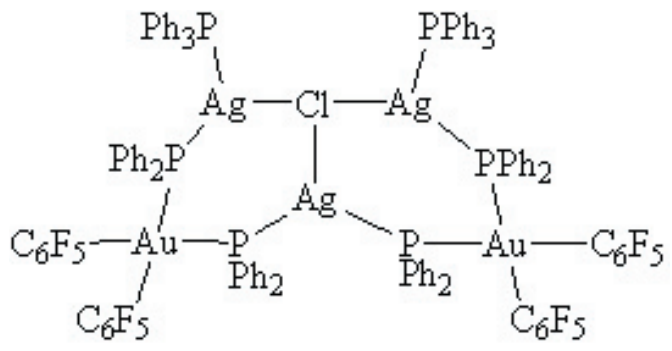

Figure 2

Apart from these mixed $\mathrm{Au}^{\mathrm{III}} / \mathrm{M}^{\mathrm{I}}$ complexes, there are some examples of diphenylphosphido groups acting as bridging ligands between gold(I) and other metal centers. A series of $\mathrm{Mn}^{1} / \mathrm{Au}^{\mathrm{I}}$ compounds can be isolated when the carbonylmanganese(I) starting cationic complexes $\left[\mathrm{MnL}_{\mathrm{n}}\left(\mathrm{PPh}_{2} \mathrm{H}\right)_{\mathrm{y}}\right]^{+}\left[\mathrm{y}=1, \mathrm{~L}_{\mathrm{n}}\right.$ $=(\mathrm{CO})_{5},(\mathrm{CO})_{3}$ (bipy), (bipy = 2,2'-bipyridine); $\left.\mathrm{y}=2, \mathrm{~L}_{\mathrm{n}}^{\mathrm{n}}=(\mathrm{CO})_{4}\right]$ are treated with $\left[\mathrm{AuCl}\left(\mathrm{PR}_{3}\right)\right]\left(\mathrm{R}=\mathrm{Ph}, p-\mathrm{C}_{6} \mathrm{H}_{4} \mathrm{Me}\right),\left[\mathrm{Au}\left(\mathrm{C}_{6} \mathrm{~F}_{5}\right)(\mathrm{tht})\right]^{\mathrm{n}}$ or $[\mathrm{AuCl}(\mathrm{tht})]$ in the presence of appropriate proportions of acetylacetonate salts, or mixtures of these reagents. ${ }^{33}$ The complexes thus prepared resemble the recently described $\mathrm{Au}^{\mathrm{III}} / \mathrm{Au}^{\mathrm{I}}$ ones and display similar structures, although a striking difference is found in the bis(pentafluorophenyl)gold(I) derivatives: while the gold(III) complex displays these units in a trans disposition, they are in a cis disposition in the manganese $(\mathrm{I})$ compound PPN $\left[\mathrm{Mn}(\mathrm{CO})_{4}\left\{\left(\mu-\mathrm{PPh}_{2}\right) \mathrm{Au}\left(\mathrm{C}_{6} \mathrm{~F}_{5}\right)\right\}_{2}\right]$.

Deprotonation of $\mathrm{PPh}_{2} \mathrm{H}$ in the iridium clusters $\left[\mathrm{Ir}_{4}(\mathrm{CO})_{1}\left(\mathrm{PPh}_{2} \mathrm{H}\right)\right]$ or $\left[\mathrm{Ir}_{4}(\mathrm{CO})_{10}\left(\mathrm{PPh}_{3}\right)\left(\mathrm{PPh}_{2} \mathrm{H}\right)\right]$ in the presence of $\left[\mathrm{Au}\left(\mathrm{PPh}_{3}\right)\right] \mathrm{PF}_{6}$ yields heteronuclear derivatives, which have a tetrahedral framework bearing a terminally bonded $\mathrm{PPh}_{2} \mathrm{AuPPh}_{3}$ ligand. ${ }^{34}$ Finally, $\left[\mathrm{Pt}_{2}\left(\mu-\mathrm{PPh}_{2}\right)_{2}\left(\mathrm{PPh}_{3}\right)_{2}\right]$ or $\left[\mathrm{Pt}_{2}\left(\mu-\mathrm{PPh}_{2}\right)\{\mu-(o-\right.$ $\left.\left.\mathrm{C}_{6} \mathrm{H}_{4} \mathrm{PPh}_{2}\right)\right\}\left(\mathrm{PPh}_{3}\right)_{2}$ ] easily react with the electrophiles $\left[\mathrm{M}\left(\mathrm{PPh}_{3}\right)\right]^{+}(\mathrm{M}=\mathrm{Cu}$, $\mathrm{Ag}, \mathrm{Au})$ to give the tri- or tetranuclear complexes $\left[\mathrm{Au}_{2} \mathrm{Pt}_{2}\left(\mu-\mathrm{PPh}_{2}\right)_{2}\left(\mathrm{PPh}_{3}\right)_{4}\right]^{2+}$ (Figure 3) or $\left[\mathrm{Pt}_{2}\left\{\mathrm{M}\left(\mathrm{PPh}_{3}\right)\right\}\left(\mu-\mathrm{PPh}_{2}\right)\left\{\mu-\left(o-\mathrm{C}_{6} \mathrm{H}_{4} \mathrm{PPh}_{2}\right)\right\}^{2}\left(\mathrm{PPh}_{3}\right)_{2}\right]^{+}$, (Figure 3b) in which $\left[\mathrm{M}\left(\mathrm{PPh}_{3}\right)\right]^{+}$fragments have been added to the Pt-Pt bonds. ${ }^{35}$ While the first species displays an original hammock-like structure, in which each $\left[\mathrm{Au}\left(\mathrm{PPh}_{3}\right)\right]^{+}$is linked to a platinum atom in a semi-bridging position between the Pt and a diphenylphosphido bridge (Au-P = 2.682(7) and 2.629(7) $\AA$ ), the latter contains. Three different bridges between the platinum centres.

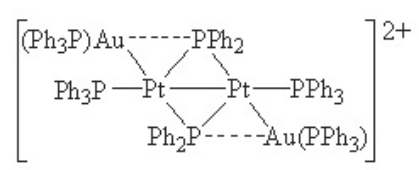

(a)

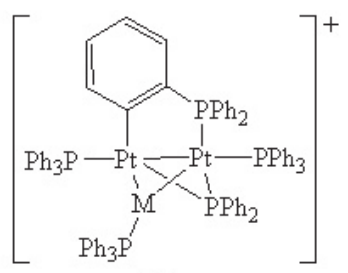

(b)
Figure 3

\section{Primary phosphine derivatives}

$\mathrm{PR}^{2-}$ units can also act as ligands in gold(I) complexes, usually acting as a bridge between two, three or four gold atoms. Thus, the primary phosphines $\mathrm{PRH}_{2}\left(\mathrm{R}=\mathrm{Ph}, o-\mathrm{C}_{4} \mathrm{H}_{6} \mathrm{Me}, 2,4,6-\mathrm{C}_{6} \mathrm{H}_{2}{ }^{\prime} \mathrm{Bu}_{3}\right)$ can be triply aurated when treated with the oxonium salt $\left[\mathrm{O}\left(\mathrm{AuPPh}_{3}\right)_{3}\right] \mathrm{BF}_{4}$ in tetrahydrofuran (THF) affording the species $\left[\left(\mu_{3}-\mathrm{PR}\right)\left(\mathrm{AuPPh}_{3}\right)_{3}\right] \mathrm{BF}_{4},{ }^{36-38}$ which display a tetrahedral environment at the phosphorus atom and intramolecular $\mathrm{Au}-\mathrm{Au}$ distances in general longer than twice the van der Waals radium of gold (1.66 $\AA){ }^{39}$ Only in the case of the bulkier phosphodiide ligand $\mathrm{P}\left(2,4,6-\mathrm{C}_{6} \mathrm{H}_{2}{ }^{\circ} \mathrm{Bu}_{3}\right)^{2-}$, two of the three metals maintain a weak interaction of 3.1546(3) $\AA$ in the solid state, ${ }^{38}$ making the third gold centre inequivalent to the other two, although they all are equivalent in solution, as NMR spectroscopy indicates. 


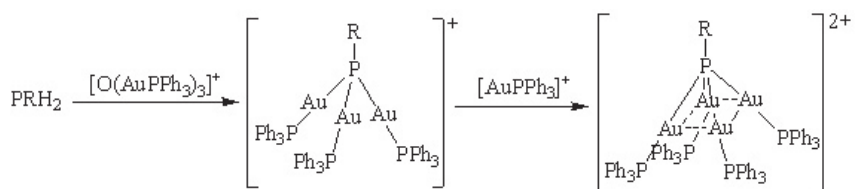

Scheme 3

The sterical demand for substituents in the oxonium salt strongly influences the nuclearity of the product, and thus, when a bulkier ligand is used, $\mathrm{P}\left(2,4,6-\mathrm{C}_{6} \mathrm{H}_{2}{ }^{\mathrm{B}} \mathrm{Bu}_{3}\right) \mathrm{H}_{2}$, a mixture of the di- and trinuclear complexes [ $\{\mu-$ $\left.\left.\mathrm{P}\left(2,4,6-\mathrm{C}_{6} \mathrm{H}_{2}{ }^{\prime} \mathrm{Bu}_{3}\right)\right\}^{2}\left(\mathrm{AuP}^{\prime} \mathrm{Bu}_{3}\right)_{2}\right]$ and $\left[\left\{\mu_{3}-\mathrm{P}\left(2,4,6-\mathrm{C}_{6} \mathrm{H}_{2}{ }^{\prime} \mathrm{Bu}_{3}\right)\right\}\left(\mathrm{AuP}^{\prime} \mathrm{Bu}_{3}\right)_{3}\right] \mathrm{BF}_{4}$ is obtained. ${ }^{38}$ The dinuclear compound can be isolated as a pure product when the reaction is carried out in equimolecular quantities. ${ }^{38}$

The electrophilic addition of a further $\left[\mathrm{AuPPh}_{3}\right]^{+}$fragment to the trinuclear cationic species affords the novel hypercoordinate dications $\left[\left(\mu_{4}-\right.\right.$ $\left.\mathrm{PR})\left(\mathrm{AuPPh}_{3}\right)_{4}\right]^{2+}\left(\mathrm{R}=o-\mathrm{C}_{4} \mathrm{H}_{6} \mathrm{Me}, 2,4,6-\mathrm{C}_{6} \mathrm{H}_{2}{ }^{ } \mathrm{Bu}_{3}\right)^{37,38}$ with a square pyramidal $\mathrm{PAu}_{4}$ core and intramolecular $\mathrm{Au} \cdots \mathrm{Au}$ contacts between the four gold atoms in the $o$-Tolyl derivative (Au-Au distances in the range 2.891(1)-3.012(1) $\AA$ ) (see scheme 3). ${ }^{37}$

Finally, a decanuclear gold(I) cluster cation of formula $\left[\mathrm{Au}_{8}(\mathrm{AuCl})_{2}\left(\mu_{3}-\right.\right.$ $\left.\left.\mathrm{P}^{\mathrm{t}} \mathrm{Bu}\right)_{2}\left\{\mu-\mathrm{P}\left({ }^{\mathrm{t}} \mathrm{Bu}\right)=\mathrm{C}\left(\mathrm{NMe}_{2}\right)_{2}\right\}_{6}\right]^{4+}$ was isolated from a dichloromethane solution after slow conversion of the resulting mixture obtained in the reaction of $\left[\mathrm{AuCl}\left(\mathrm{PPh}_{3}\right)\right]$ with two equivalents of $\mathrm{BuP}=\mathrm{C}\left(\mathrm{NMe}_{2}\right)_{2}{ }^{40} \mathrm{This}$ compound features six edge-bridging phosphinoalkene ligands and two $\mu_{3}$-tert-butylphosphodiide ligands (see Figure 4). Eight gold atoms form a puckered ladder made up of three quadrangles, the central one capped on both faces by a $\mathrm{BuPAuCl}$ entity, showing Au-Au distances ranging form 3.030(1) to 3.426(1) $\AA$.

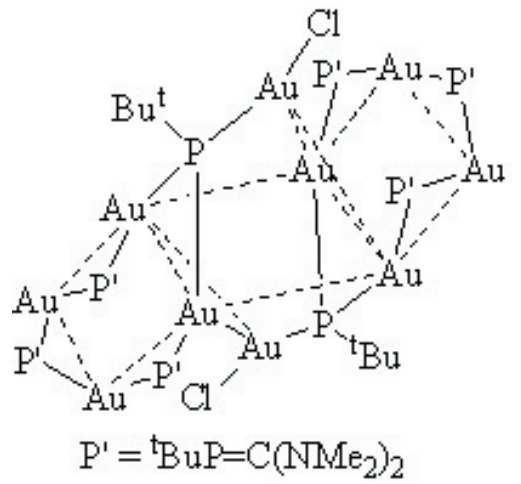

Figure 4.-

As commented above for diphenylphosphido derivatives, the use of pentafluorophenyl rings enabled the synthesis of stable gold(III) complexes, and thus, cyclic and acyclic phosphino, phosphido and phosphodiido derivatives of the primary phosphine $\mathrm{PPhH}_{2}$ were prepared in high yields. ${ }^{41}$ Treatment of $\left[\mathrm{Au}\left(\mathrm{C}_{6} \mathrm{~F}_{5}\right)_{3}\left(\mathrm{PPhH}_{2}\right)\right]$ with gold(I), silver(I) or gold(III) reagents in the presence of a deprotonanting agent leads to the di- or trinuclear phenylphosphido derivatives $\left[\mathrm{Au}\left(\mathrm{C}_{6} \mathrm{~F}_{5}\right)_{3}(\mu-\mathrm{PPhH}) \mathrm{AuPR}_{3}\right](\mathrm{R}=\mathrm{Ph}, \mathrm{Me})$, $\operatorname{PPN}\left[\left\{\mathrm{Au}\left(\mathrm{C}_{6} \mathrm{~F}_{5}\right)_{3}\right\}_{2}(\mu-\mathrm{PPhH})\right]$ or $\mathrm{PPN}\left[\left\{\mathrm{Au}\left(\mathrm{C}_{6} \mathrm{~F}_{5}\right)_{3}(\mu-\mathrm{PPhH})\right\}_{2} \mathrm{M}\right](\mathrm{M}=\mathrm{Au}$ $\mathrm{Ag}$ ), which resemble the diphenylphosphide ones described in the previous section, or trinuclear phenylphosphodiide $\left[\mathrm{Au}\left(\mathrm{C}_{6} \mathrm{~F}_{5}\right)_{3}\left(\mu_{3}-\mathrm{PPh}\right)\left\{\mathrm{Au}\left(\mathrm{PPh}_{3}\right)\right\}_{2}\right]$. The anionic complex PPN $\left.\left[\mathrm{Au}\left(\mathrm{C} \mathrm{F}_{5}\right)\right\}_{2}(\mu-\mathrm{PPhH})\right]$ further reacts with similar gold(I) precursors to afford higher nuclearity phosphodiide anions, such as the trinuclear $\left[\left\{\mathrm{Au}\left(\mathrm{C}_{6} \mathrm{~F}_{5}\right)_{3}\right\}_{2}\left(\mu_{3}-\mathrm{PPh}\right) \mathrm{Au}\left(\mathrm{PPh}_{3}\right)\right]^{-},\left[\left\{\mathrm{Au}\left(\mathrm{C}_{6} \mathrm{~F}_{5}\right)_{3}\right\}_{2}\left(\mu_{3}-\mathrm{PPh}\right) \mathrm{Au}\left(\mathrm{C}_{6} \mathrm{~F}_{5}\right)\right]^{2-}$ or the pentanuclear trianion $\left[\left\{\left(\mathrm{Au}\left(\mathrm{C}_{6} \mathrm{~F}_{5}\right)_{3}\right)_{2}\left(\mu_{3}-\mathrm{PPh}\right)\right\}_{2} \mathrm{Au}\right]^{3-}($ scheme 4$)$.

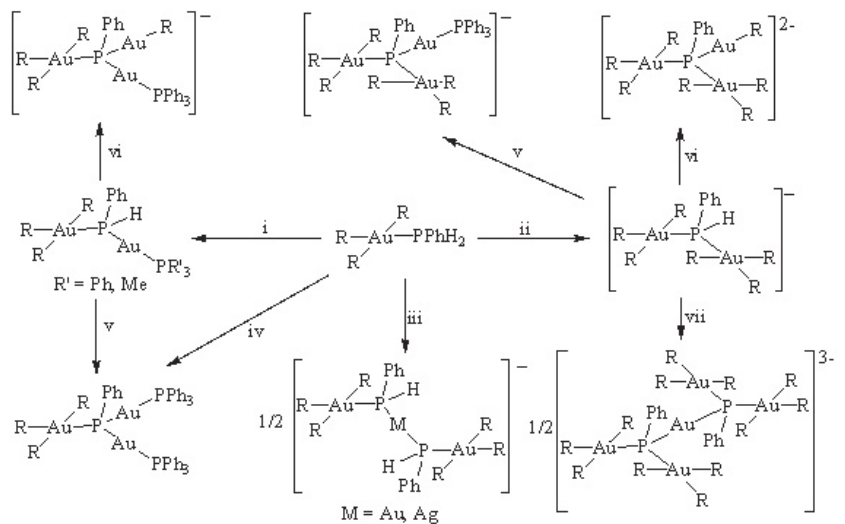

Scheme 4. $\mathrm{R}=\mathrm{C}_{6} \mathrm{~F}_{5}$. i) $\left[\mathrm{Au}(\mathrm{acac})\left(\mathrm{PPh}_{3}\right)\right]$ or $\left[\mathrm{AuCl}\left(\mathrm{PMe}_{3}\right)\right]+\mathrm{Tl}(\mathrm{acac})$; ii) $\left[\mathrm{AuR}_{3}\right.$ (tht) $]+\mathrm{PPN}(\mathrm{acac}) ;$ iii) $1 / 2 \mathrm{PPN}\left[\mathrm{Au}\left(\mathrm{acac}_{2}\right]\right.$ or $1 / 2 \mathrm{Ag}\left(\mathrm{OClO}_{3}\right)+\mathrm{PPN}(\mathrm{acac})$; iv) $2\left[\mathrm{Au}(\mathrm{acac})\left(\mathrm{PPh}_{3}\right)\right]$; v) $\left[\mathrm{Au}(\mathrm{acac})\left(\mathrm{PPh}_{3}\right)\right]$; vi) $[\mathrm{AuR}($ tht $)]+\mathrm{PPN}(\mathrm{acac})$; vii) $1 / 2 \mathrm{PPN}\left[\mathrm{Au}(\mathrm{acac})_{2}\right]$

Very interestingly, treatment of $\left[\mathrm{Au}\left(\mathrm{C}_{6} \mathrm{~F}_{5}\right)_{2}(\mu-\mathrm{Cl})\right]_{2}$ with $\mathrm{PPhH}_{2}$ results in the formation of the cyclic trinuclear complex $\left[\mathrm{Au}\left(\mathrm{C}_{6} \mathrm{~F}_{5}\right)_{2}(\mu-\mathrm{PPhH})\right]_{3}$ instead of a dinuclear derivative similar to that obtained with diphenylphsophine, and whose crystal structure shows a hexanuclear ring of alternating square-planar gold(III) and tetrahedral phosphorus atoms in a twisted boat conformation. It further reacts with $\left[\mathrm{Au}(\mathrm{acac})\left(\mathrm{PPh}_{3}\right)\right]$ to afford the tetranuclear phosphide/phosphodiide derivative $\left[\left\{\mathrm{Au}\left(\mathrm{C}_{6} \mathrm{~F}_{5}\right)_{2}(\mu-\mathrm{PPhH})\right\}_{2}\left\{\mathrm{Au}\left(\mathrm{C}_{6} \mathrm{~F}_{5}\right)_{2}\left(\mu_{3}-\mathrm{PPh}\right) \mathrm{Au}\left(\mathrm{PPh}_{3}\right)\right\}\right]$ (scheme 5).

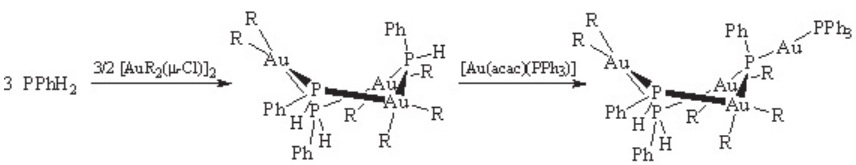

Scheme 5. $\mathrm{R}=\mathrm{C}_{6} \mathrm{~F}_{5}$

There are also some examples with $\mathrm{PCy}^{2-}$ acting as bridge between three or even four metal centres, as the mono- and diaurated $\mathrm{Mn}^{\mathrm{I}} / \mathrm{Au}^{\mathrm{I}}$ complexes $\left[\left\{\mathrm{Mn}(\mathrm{CO})_{4}\right\}_{2}(\mu-\mathrm{H})\left(\mu_{3}-\mathrm{PCy}\right)\left(\mathrm{AuPR}_{3}\right)\right]\left(\mathrm{R}=\mathrm{Ph}, \mathrm{Cy}, p-\mathrm{C}_{6} \mathrm{H}_{4} \mathrm{~F}, p-\mathrm{C}_{6} \mathrm{H}_{4} \mathrm{OMe}\right)$ and the pairs of isomers $\left[\left\{\mathrm{Mn}(\mathrm{CO})_{4}\right\}_{2}\left(\mu-\mathrm{AuPPh}_{3}\right)\left(\mu_{3}-\mathrm{PCy}\right)\left(\mathrm{AuPPh}_{3}\right)\right]$ and $\left[\left\{\mathrm{Mn}(\mathrm{CO})_{4}\right\}_{2}\left(\mu_{4}-\mathrm{PCy}\right)\left(\mathrm{AuPPh}_{3}\right)_{2}\right]$, formed by reaction of $\left[\left\{\mathrm{Mn}(\mathrm{CO})_{4}\right\}_{2}(\mu-\right.$ $\mathrm{H})(\mu-\mathrm{PCyH})]$ with $\left[\mathrm{AuCl}\left(\mathrm{PR}_{3}\right)\right]$ in the presence of a non-nucleophilic base. ${ }^{42}$ It's worth mentioning that, in contrast to what has been reported for most gold phosphides, the latter tetranuclear compound shows an intramolecular $\mathrm{Au} \cdots \mathrm{Au}$ contact of 2.9212(1) $\AA$, as well as a Mn-Mn and a Mn-Au bond of 2.846(2) and 2.762(2) $\AA$, respectively, with the other two metals $\left(\mathrm{Mn}^{\mathrm{I}}\right.$ and $\left.\mathrm{Au}^{\mathrm{I}}\right)$ located at 3.780(2) $\AA$ (Figure 5).

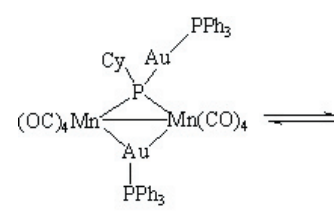

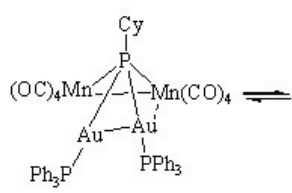

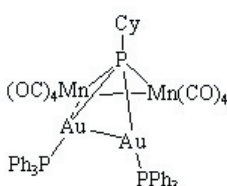

Figure 5.-

The variation of the reagent $\left[\mathrm{AuCl}\left(\mathrm{PR}_{3}\right)\right]$ and the solvent in the reaction system showed that the isomerization equilibrium depends on electronic and/or steric factors and on the polarity of the solvent. This, in the case of the $\mathrm{PCy}_{3}$ derivative it was possible to separate the $\mu_{3}$-brigde isomer $\left[\left\{\mathrm{Mn}(\mathrm{CO})_{4}\right\}_{2}(\mu-\right.$ $\left.\left.\mathrm{AuPCy}_{3}\right)\left(\mu_{3}-\mathrm{PCy}\right)\left(\mathrm{AuPCy}_{3}\right)\right]$, due to the bigger steric strain in the related $\mu_{4}-\mathrm{P}$ bridged isomer. ${ }^{42 b}$ In contrast, the related dirhenium/gold complexes $\left[\left\{\operatorname{Re}(\mathrm{CO})_{4}\right\}_{2}(\mu-\mathrm{H})\left(\mu_{3}-\mathrm{PCy}\right)\left(\mathrm{AuPPh}_{3}\right)\right]$ and $\quad\left[\left\{\operatorname{Re}(\mathrm{CO})_{4}\right\}_{2}\left(\mu-\mathrm{AuPPh}_{3}\right)\left(\mu_{3}-\right.\right.$ $\left.\mathrm{PCy})\left(\mathrm{AuPPh}_{3}\right)\right]$ show no tendency for isomerization. ${ }^{43}$

\section{Primary diphosphine derivatives}

When a primary diphosphine is employed, higher nuclearity compounds can be obtained. Thus, the aromatic diphosphines 1,2- and 1,4-diphosphinobenzene can be triply aurated at each phosphorus upon reaction with two equivalents of 
$\left[\mathrm{O}\left(\mathrm{AuPR}_{3}\right)_{3}\right] \mathrm{BF}_{4}$, leading to the hexanuclear cations $\left[1,2-\mathrm{C}_{6} \mathrm{H}_{4}\left\{\mathrm{P}\left(\mathrm{AuPPh}_{3}\right)_{3}\right\}_{2}\right]^{2+}$ ${ }^{44}$ or $\left[1,4-\mathrm{C}_{6} \mathrm{H}_{4}\left\{\mathrm{P}\left(\mathrm{AuPR}_{3}\right)_{3}\right\}_{2}\right]^{2+}\left(\mathrm{R}=\mathrm{Ph},{ }^{\mathrm{t}} \mathrm{Bu}\right)$ (Figure 6a) ${ }^{45}$ Even an octanuclear complex, $\left[1,4-\mathrm{C}_{6} \mathrm{H}_{4}\left\{\mathrm{P}\left(\mathrm{AuPh}_{3}\right)_{4}\right\}_{2}\right]^{4+}$ (Figure 6b), can be obtained in quantitative yield by reaction of $1,4-\mathrm{C}_{6} \mathrm{H}_{4}\left(\mathrm{PH}_{2}\right)_{2}$ with two equivalents of an equimolar mixture of $\left[\mathrm{O}\left(\mathrm{AuPPh}_{3}\right)_{3}\right] \mathrm{BF}_{4}$ and $\left[\mathrm{AuPPh}_{3}\right] \mathrm{BF}_{4}{ }^{45}$ It is worth noting that this doubly tetraaurated complex cation is stable in spite of its exceedingly high positive charge, a stability presumably favoured by $\mathrm{Au} \cdots \mathrm{Au}$ bonding interactions in each $\mu_{4}-\mathrm{P}\left(\mathrm{AuPPh}_{3}\right)_{4}{ }^{2+}$ unit.

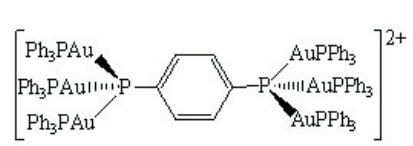

a)

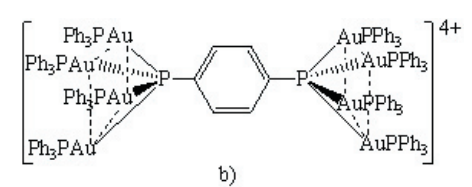

b)
Figure 6.-

On the other hand, a number of cyclic or non cyclic gold(III) phosphinophosphides or diphosphides were synthesized from 1,2-diphosphinobenzene (scheme 6) ${ }^{46}$ The diphosphino complex $\left[\left\{\mathrm{Au}\left(\mathrm{C}_{6} \mathrm{~F}_{5}\right)_{3}\right\}\left(1,2-\mathrm{PH}_{2} \mathrm{C}_{6} \mathrm{H}_{4} \mathrm{PH}_{2}\right)\right]$ or the phosphane-phosphide $\left[\left\{\mathrm{Au}\left(\mathrm{C}_{6} \mathrm{~F}_{5}\right)_{3}\right\}_{2}\left(1,2-\mathrm{PHC}_{6} \mathrm{H}_{4} \mathrm{PH}_{2}\right)\right]$ react with suitable pentafluorophenylgold(III) precursors in the presence of free or coordinated acetylacetonate to afford the di- or trinuclear species shown in scheme 6 . In some of these reactions, the migration of one $\mathrm{Au}\left(\mathrm{C}_{6} \mathrm{~F}_{5}\right)_{3}$ group from one phosphorus to the other is observed. In the case of trans- $\left[\left\{\mathrm{Au}\left(\mathrm{C}_{6} \mathrm{~F}_{5}\right)_{3}\right\}(1,2-\right.$ $\left.\left.\mathrm{PHC}_{6} \mathrm{H}_{4} \mathrm{PH}\right)\left\{\mathrm{Au}\left(\mathrm{C}_{6} \mathrm{~F}_{5}\right)_{2} \mathrm{Cl}\right\}\left\{\mu-\mathrm{Au}\left(\mathrm{C}_{6} \mathrm{~F}_{5}\right)_{2}\right\}\right]$, both the acetylacetonate and one of the chlorine atoms of $\left[\mathrm{Au}(\mu-\mathrm{Cl})\left(\mathrm{C}_{6} \mathrm{~F}_{5}\right)_{2}\right]_{2}$ act as deprotonating agents in a reaction that occurs with the breaking of the dinuclear compound and that leads to a complex with three different pentafluorophenylgold(III) fragments.

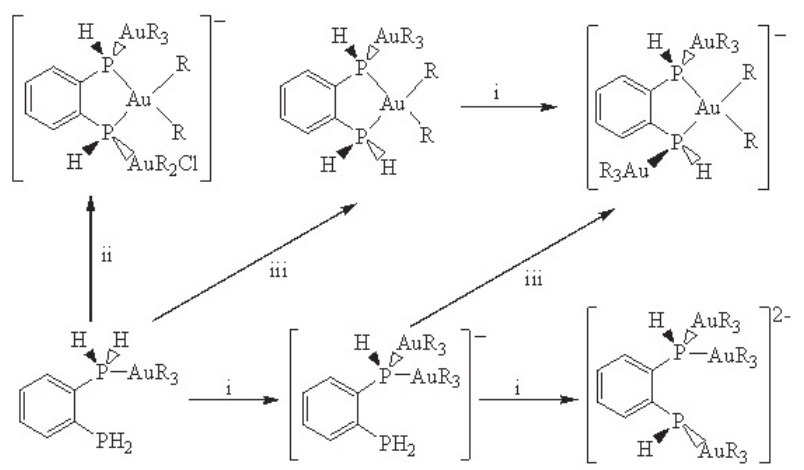

Scheme 6. $\mathrm{R}=\mathrm{C}_{6} \mathrm{~F}_{5}$; i) $\left[\mathrm{AuR}_{3}(\right.$ tht $\left.)\right]+$ acac; ii) $\left[\mathrm{Au}\left(\mu-\mathrm{Cl}_{2} \mathrm{R}_{2}\right]_{2}+\right.$ acac; iii) $\left[\operatorname{AuR}_{2}(\mathrm{acac})\right]$.

$\left[\left\{\mathrm{Au}\left(\mathrm{C}_{6} \mathrm{~F}_{5}\right) 3\right\}_{2}\left(1,2-\mathrm{PHC}_{6} \mathrm{H}_{4} \mathrm{PH}_{2}\right)\right]^{-}$has also been shown to be a useful starting material for the synthesis of mixed $\mathrm{Au}^{\mathrm{II}} / \mathrm{M}^{\mathrm{I}}(\mathrm{M}=$ coinage metal $)$ diphosphide or diphosphodiide compounds following a similar synthetic strategy ${ }^{46}$ Thus, its reaction with phosphino- or pentafluorophenylgold(I) or silver(I) complexes in the presence of the same deprotonant agent leads to trinuclear diphosphides displaying a tricoordinated gold(I) or silver(I) centre (see scheme 7). The bridging chlorine atom of $\left[\left\{\mathrm{Au}\left(\mathrm{PPh}_{3}\right)\right\}_{2}(\mu-\mathrm{Cl})\right]^{+}$is able to extract one phosphinic proton from $\left[\left\{\mathrm{Au}\left(\mathrm{C}_{\mathrm{F}_{5}}\right)_{3}\right\}\left(1,2-\mathrm{PHC}_{6} \mathrm{H}_{4} \mathrm{PH}_{2}\right)\right]^{-}$to yield the tetranuclear diphosphodiide complex $\left[\left\{\mathrm{Au}\left(\mathrm{C}_{6} \mathrm{~F}_{5}\right)_{3}\right\}\left(\mathrm{AuPPh}_{3}\right)\left(1,2-\mathrm{PHC}_{6} \mathrm{H}_{4} \mathrm{P}\right.\right.$ $\left.\mathrm{H})\left\{\mathrm{Au}\left(\mathrm{C}_{6} \mathrm{~F}_{5}\right)_{3}\right\}\left(\mathrm{AuPPh}_{3}\right)\right]$. As in other cases, the reaction takes place with the concomitant migration of one $\mathrm{Au}\left(\mathrm{C}_{6} \mathrm{~F}_{5}\right)$ group from one phosphorus to the other, leading to a more symmetric product. Finally, the hexanuclear diphosphodiides $\left[\left\{\mathrm{Au}\left(\mathrm{C}_{6} \mathrm{~F}_{5}\right)_{3}\right\}\left(1,2-\mathrm{PC}_{6} \mathrm{H}_{4} \mathrm{P}\right)\left\{\mathrm{Au}\left(\mathrm{C}_{6} \mathrm{~F}_{5}\right)_{3}\right\}\{\mu-\mathrm{M}(\mathrm{dppe}) \mathrm{M}\}_{2}\right](\mathrm{M}=\mathrm{Cu}, \mathrm{Ag}, \mathrm{Au})$ were prepared in good yields using similar procedures. The crystal structures of the $\mathrm{Au}^{\text {III }} / \mathrm{Au}^{\mathrm{I}}$ and $\mathrm{Au}^{\text {III }} / \mathrm{Ag}^{\mathrm{I}}$ species were determined, showing discrete molecules consisting of a 16-membered bicycle formed by the ipso carbon atoms and both phosphorus of the 1,2-diphosphodiidebenzene ligand and two $\mathrm{M}(\mathrm{dppe}) \mathrm{M}$ units, with each phosphorus of the diphosphodiide also bonded to a tris(pentafluorop henyl)gold(III) unit. An important feature in these structures is the presence of intramolecular $\mathrm{M}^{\mathrm{I} \cdots} \mathrm{M}^{\mathrm{I}}$ contacts of 2.9385(5), 3.0273(5) and 3.1105(5) $\AA$ for $\mathrm{M}$ $=\mathrm{Au}$ or 2.9215(15), 2.9822(16) and 3.0514(16) $\AA$ for $\mathrm{M}=\mathrm{Ag}$.

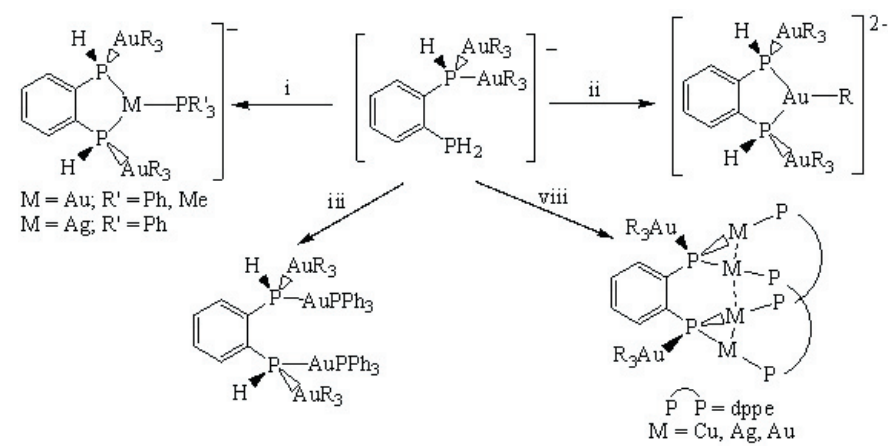

Scheme 7. $\mathrm{R}=\mathrm{C}_{6} \mathrm{~F}_{5}$; i) $\left[\mathrm{Au}(\mathrm{acac})\left(\mathrm{PPh}_{3}\right)\right]$ or $\left[\mathrm{AuCl}\left(\mathrm{PMe}_{3}\right)\right]+\mathrm{Tl}(\mathrm{acac})$ or $\left.\left[\mathrm{Ag}(\mathrm{TfO})\left(\mathrm{PPh}_{3}\right)\right]+\mathrm{PPN}(\mathrm{acac}) ; \mathrm{ii}\right)[\mathrm{AuR}(\mathrm{tht})]+$ acac; iii $)\left[\left\{\mathrm{Au}\left(\mathrm{PPh}_{3}\right)\right\}_{2}(\mu-\mathrm{Cl})\right]+$; iv) $2\left[(\mathrm{AuCl})_{2}(\mathrm{dppe})\right]+4 \mathrm{Ag}\left(\mathrm{OClO}_{3}\right)+3 \mathrm{PPN}(\mathrm{acac})$ or $2\left[\mathrm{M}_{2}(\mathrm{dppe})\right]\left(\mathrm{ClO}_{4}\right)_{2}(\mathrm{M}$ $=\mathrm{Ag}, \mathrm{Cu})+3$ PPN(acac $)$.

\section{$\mathrm{PH}_{3}$ derivatives}

A series of complexes containing a central phosphorus surrounded by a varying number of $\left[\mathrm{AuPR}_{3}\right]^{+}$units was described by Schmidbaur some years ago. ${ }^{36,47}$ Most were prepared from tris(trimethylsilyl)phosphine and gold(I) cations of the type $\left.\left[\mathrm{O}(\mathrm{AuPR})_{3}\right)_{3}\right]^{+}$or $\left[\mathrm{AuPPh}_{3}\right]^{+}$in the presence of an excess of KF, and from these reactions the tetra-, penta- or hexanuclear compounds $\left[\mathrm{P}\left(\mathrm{AuP} \mathrm{Pu}_{3}\right)_{4}\right]^{+},\left[\mathrm{P}(\mathrm{AuPPh})_{5}\right)^{2+}$ or $\left[\mathrm{P}(\mathrm{AuPR})_{3}\right]^{3+}\left(\mathrm{R}=\mathrm{Ph},{ }^{\mathrm{P}} \mathrm{Pr},{ }^{\mathrm{t}} \mathrm{Bu}\right)^{47 \mathrm{~b}}$ were isolated as shown in scheme 8 . The crystal structure of the former shows a distorted quasi-tetrahedral $\mathrm{P}(\mathrm{AuP})_{4}$ skeleton with very weak aurophilic interactions between the edges of the $\mathrm{AuP}_{4}$ unit $(\mathrm{Au}-\mathrm{Au}$ distances in the range 3.4395(5)-4.3314(5) $\AA$ ), which are responsible for the distortion of the tetrahedron but also contributed to the stabilization of the system. ${ }^{47 a}$ Although the solid state structures of the other two compounds have not been determined, a trigonal-bipyramidal structure, which apparently is fluxional in solution, or a distorted octahedral $\mathrm{PAu}_{6}$ core is tentatively proposed for the di- or trication, respectively. ${ }^{36,47}$

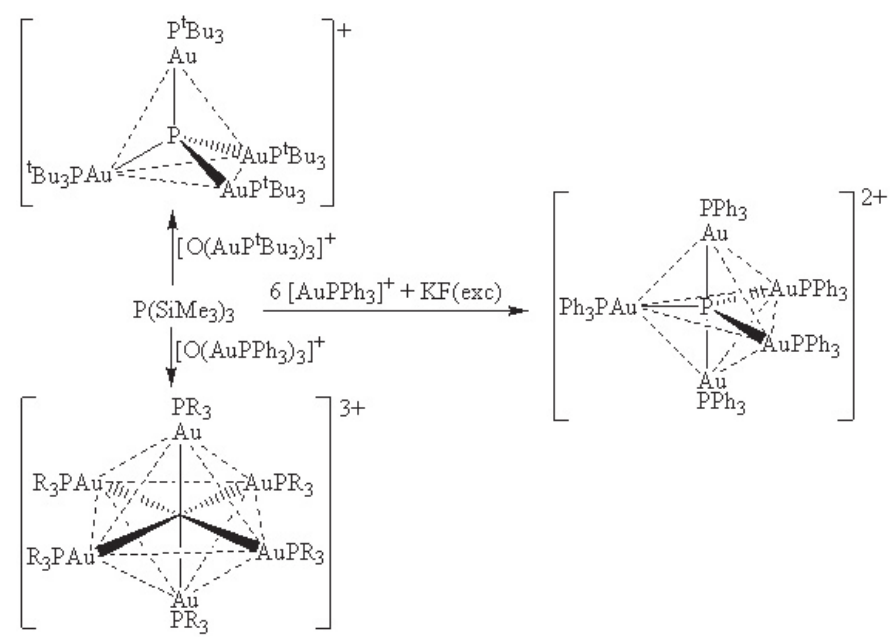

Scheme 8

The reaction of $\mathrm{PH}_{3}$ with $\left[\mathrm{O}\left(\mathrm{AuPPh}_{3}\right)_{3}\right]^{+}$and $\mathrm{NaBF}_{4}$ in tetrahydrofuran at low temperature leads to a mixture of products, ${ }^{48}$ one of which is identified as $[\mathrm{P}$ $\left.(\mathrm{AuPPh})_{4}\left\{\mathrm{Au}\left(\mathrm{PPh}_{3}\right)_{2}\right\}\right]^{2+}$ (Equation 2). Its crystal structure can be described as an adduct of $\left[\mathrm{P}(\mathrm{AuPPh})_{4}\right]^{+}$and $\left[\mathrm{Au}\left(\mathrm{PPh}_{3}\right)_{2}\right]^{+}$with pentacoordinate phosphorus atoms in an irregular coordination geometry and with gold-gold contacts between 2.895(1) and 3.051(1) $\AA$, stronger than in $\left[\mathrm{P}\left(\mathrm{AuP}^{\mathrm{t}} \mathrm{Bu}_{3}\right)_{4}\right]^{+}$. Other products are $\left[\mathrm{P}(\mathrm{AuPPh})_{5}\right)^{2+}$ and $\left[\mathrm{Au}\left\{\mathrm{P}(\mathrm{AuPPh})_{4}\right\}_{2}\right]^{3+}$, the latter considered as the result of the interaction of two $\left[\mathrm{P}\left(\mathrm{AuPPh}_{3}\right)_{4}\right]^{+}$fragments with a further gold(I) centre. 


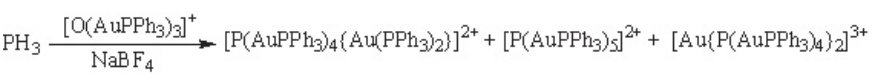

Eqn. 2

Apart from these polyaurated cations, some heteronuclear complexes deriving from $\mathrm{PH}_{3}$ have also been described, such as the dinuclear gold/ osmium $\mathrm{PH}_{2}$ bridging complexes $\left[\mathrm{OsX}(\mathrm{CO})_{2}\left(\mathrm{PPh}_{3}\right)_{2}\left(\mu-\mathrm{PH}_{2}\right) \mathrm{AuI}\right](\mathrm{X}=\mathrm{Cl}$, $\left.\mathrm{H}, \quad \eta^{1}-\mathrm{OC}(=\mathrm{O}) \mathrm{Me}\right), \quad\left[\mathrm{Os}\left(\eta^{2}-\mathrm{O}_{2} \mathrm{CMe}\right)(\mathrm{CO})\left(\mathrm{PPh}_{3}\right)_{2}\left(\mu-\mathrm{PH}_{2}\right) \mathrm{AuI}\right]$ or $\left[\mathrm{Os}\left(\eta^{2}-\right.\right.$ $\left.\left.\mathrm{S}_{2} \mathrm{CNMe}_{2}\right)(\mathrm{CO})\left(\mathrm{PPh}_{3}\right)_{2}\left(\mu-\mathrm{PH}_{2}\right) \mathrm{AuI}\right]{ }^{49}$ obtained by adding an AuI fragment to the phosphorus lone pair in the corresponding osmium starting complex (Equation 3).

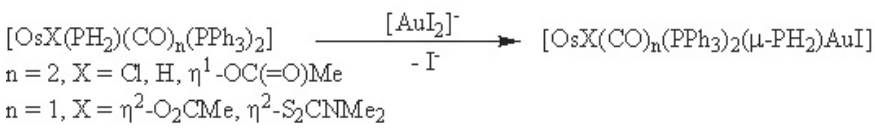

Eqn. 3

A series of iron/gold clusters containing bridging $\mu_{4}-\mathrm{P}^{3-}$ and terminal $\mu_{3}$ $\mathrm{PMe}^{2-}$ fragments, the simplest one being $\left[\left\{\mathrm{Fe}_{3}(\mathrm{CO})_{9}\left(\mu_{3}-\mathrm{PMe}\right)\left(\mu_{4}-\mathrm{P}\right)\right\}_{2} \mathrm{Au}\right]^{-50}$ can be prepared through cluster-linking reactions using a gold(I) ion linker metal centre as summarized in Equation 4.

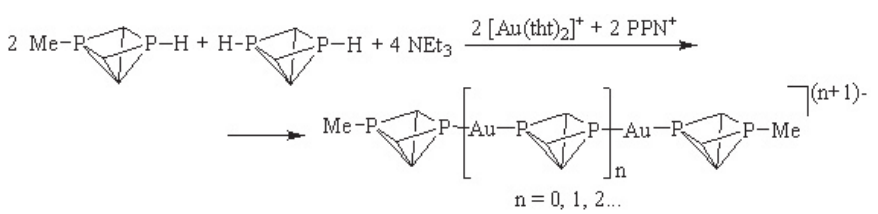

Eqn. 4

Finally, the reaction of the monoprotonated derivative $\left[\left\{\mathrm{MoCp}(\mathrm{CO})_{2}\right\}_{2}(\mu-\right.$ $\left.\mathrm{H})\left(\mu-\mathrm{PH}_{2}\right)\right]$ with $\left[\mathrm{AuCl}\left(\mathrm{PPh}_{3}\right)\right]$ and $\mathrm{KH}$ as deprotonating agent produced the new phosphido complex $[\{\mathrm{MoCp}(\mathrm{CO})\}(\mu-\mathrm{H})(\mu-\mathrm{PH})(\mathrm{AuPPh})]{ }^{51}$ which resembles the manganese derivatives $\left[\left\{\mathrm{Mn}(\mathrm{CO})_{4}\right\}_{2}(\mu-\mathrm{H})\left(\mu_{3}-\mathrm{PCy}\right)\left(\mathrm{AuPR}_{3}\right)\right]$ described above. In contrast, when the same reaction is carried out with the chromium precursor the novel gold/chromium complex $\left[\left\{\mathrm{CrCp}(\mathrm{CO})_{2}\right\}_{6}\left(\mathrm{P}_{3} \mathrm{Au}_{3}\right)\right]$, in an unusual bonding situation, is isolated (see scheme 9). The molecular structures of both complexes have been established by X-ray diffraction methods, the latter revealing a planar $\mathrm{Au}_{3} \mathrm{P}_{3}$ six-membered ring, where each distorted tetrahedrally surrounded phosphido ligand binds two gold atoms as well as two $\mathrm{CrCp}(\mathrm{CO})_{2}$ moieties. The $\mathrm{Au}-\mathrm{Au}$ distances in this compound indicate essentially no $\mathrm{Au} \cdots \mathrm{Au}$ interaction.

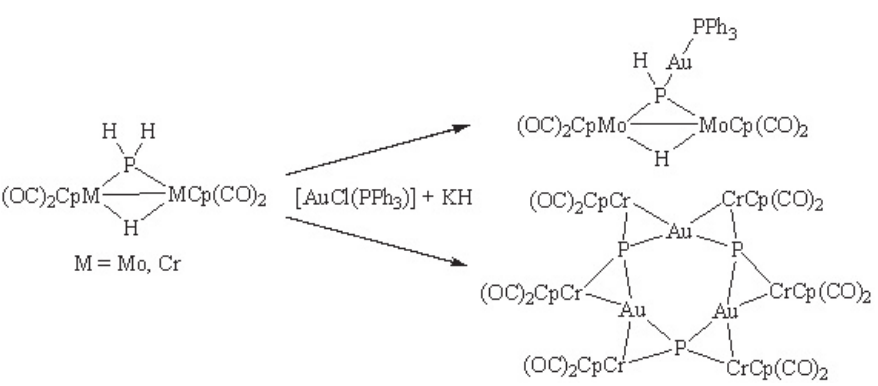

\section{Scheme 9}

As conclusion, this area of research, far from being run out, is a field of interest at present because it allows the preparation of homo- or heteropolynuclear complexes with very interesting structures, and in which, thanks to the presence of a small atom in the proximity of some metal centres, the presence of intermetallic contacts can be sometimes favoured. As is known, these type of metallophilic interactions are often responsible for interesting optical properties, such as luminescence, area with an increasing importance in the last years.

\section{REFERENCES}

1. M. Westerhausen, M. Krofta, P. Mayer, M. Warchhold, H. Nöth, Inorg. Chem., 39, 4721 (2000).

2. R. D. Culp, A. H. Cowley, A. Decken, R. A. Jones, M. R. Bond, L. M. Mokry, C. J. Carrano, Inorg. Chem., 36, 5165 (1997).

3. O. T. Beachley, Jr., S. L. Chao, M. R. Churchill, C. H. Lake, Organometallics, 15, 3088 (1996).

4. K. Izod, P. O'Shaughnessy, J. M. Sheffield, W. Clegg, S. T. Liddle, Inorg. Chem., 39, 4741 (2000).

5. a) B. F. G. Johnson, J. Lewis, E. Nordlander, P. R. Raithby, C. E. Housecroft, Inorg. Chim. Acta, 259, 345 (1997). b) S. Doherty, M. Waugh, T.H. Scanlan, M. R. J. Elsegood, W. Clegg, Organometallics, 18, 679 (1999). c) W.-Y. Wong, F.-L. Ting, W.-L. Lam, J. Chem. Soc., Dalton Trans., 2981 (2001). d) K. Eichele, R. E. Wasylishen, J. F. Corrigan, N. J. Taylor, A. J. Carty, K. W. Feindel, G. M. Bernard, J. Am. Chem. Soc., 124, 1541 (2002).

6. a) G. A. Acum, M. J. Mays, P. R. Raithby, H. R. Powel, G. A. Solan, J. Chem. Soc., Dalton Trans., 3427 (1997). b) K. Wang, T. J. Emge, A. S. Goldman, Inorg. Chim. Acta, 255, 395 (1997).

7. L. Y. Goh, Z. Weng, W. K. Leong, J. J. Vittal, I. Haiduc, Organometallics, 21, 5287 (2002).

8. P. Legzdins, K. J. Ross, S. F. Sayers, S. J. Rettig, Organometallics, 16, 190 (1997).

9. a) S.-M. Hsiao, S.-G. Shyu, Organometallics, 17, 1151 (1998). b) S.-G. Shyu, R. Singh, K.-J. Lin, Organometallics, 17, 4739 (1998).

10. J. E. Davies, M. J. Mays, P. R. Raithby, A. D. Woods, Chem. Commun., 2455 (1999).

11. M. Basato, E. Brescacin, E. Tondello, G. Valle, Inorg. Chim. Acta, 323, 147 (2001)

12. a) M. E. García, V. Riera, M. A. Ruiz, D. Sáez, J. Vaissermann, J. C. Jeffery, J. Am. Chem. Soc., 124, 14304 (2002). b) M. E. García, V. Riera, M. A. Ruiz, M. T. Rueda, D. Sáez, Organometallics, 21, 5515 (2002).

13. R. Melenkivitz, D. J. Mindiola, G. L. Hillhouse, J. Am. Chem. Soc., 124, 3846 (2002)

14. a) C. Mealli, A. Ienco, A. Galindo, E. Pérez Carreño, Inorg. Chem., 38, 4620 (1999). b) A. A. Palacios, P. Alemany, S. Álvarez, J. Chem. Soc., Dalton Trans., 2235 (2002).

15. R. Giannandrea, P. Mastrorilli, C. F. Nobile, Inorg. Chim. Acta, 284, 116 (1999).

16. I. V. Kourkine, M. B. Chapman, D. S. Glueck, K. Eichele, R. E. Wasylishen, G. P. A. Yap, L. M. Liable-Sands, A. L. Rheingold, Inorg. Chem., 35, 1478 (1996).

17. W. Schuh, H. Wachtler, G. Laschober, H. Kopacka, K. Wurst, P. Peringer, Chem. Commun., 1181 (2000)

18. a) L. R. Falvello, J. Forniés, J. Gómez, E. Lalinde, A. Martín, M. T. Moreno, J. Sacristán, Chem. Eur. J., 5, 474 (1999). b) E. Alonso, J. Forniés, C. Fortuño, A. Martín, A. Guy, Organometallics, 20, 850 (2001).

19. V. Cittadini, P. Leoni, L. Marchetti, M. Pasquali, A. Albinati, Inorg. Chim. Acta, 330, 25 (2002).

20. C. Archambault, R. Bender, P. Braunstein, Y. Dusausoy, J. Chem. Soc., Dalton. Trans., 4084 (2002).

21. a) A. J. Carty, $A d v$. Chem. Ser., 196, 163 (1982). b) A. D. Harley, G. J. Guskey, G. L. Geoffroy, Organometallics, 2, 53 (1983). c) V. D. Patel, N. J. Taylor, A. J. Carty, J. Chem. Soc.; Chem. Commun., 99 (1984). d) A. J. Carty, G. Hogarth, G. D. Enright, J. W. Steed, D. Georganopoulou, Chem. Commun., 1499 (1999).

22. J. Vicente, M.T. Chicote, P.G. Jones, Inorg. Chem., 32, 4960 (1993).

23. D.B. Dyson, R.V. Parish, C.A. McAuliffe, R.G. Pritchard, R. Fields, B. Beagley, J. Chem. Soc., Dalton Trans., 907 (1989).

24. R.J. Puddephatt, P.J. Thompson, J. Organomet. Chem., 117, 395 (1976).

25. J. Vicente, M.T. Chicote, I. Saura-Llamas, M.C. Lagunas, J. Chem. Soc., Chem. Commun., 915 (1992).

26. a) D. M. Stefanescu, H. F. Yuen, D. S. Glueck, J. A. Golen, A. L. Rheingold, Angew.Chem., Int. Ed. Engl., 42, 1046 (2003). b) D. M. Stefanescu, H. F. Yuen, D. S. Glueck, J. A. Golen, L. N. Zakharov, C. D. Incarvito, A. L. Reingold, Inorg.Chem., 42, 8891 (2003).

27. R. G. Pritchard, D. B. Dyson, R. V. Parish, C. A. McAuliffe, B. Beagley, J. Chem. Soc., Chem. Commun., 371 (1987).

28. M. C. Blanco, E. J. Fernández, A. K. Fischer, P. G. Jones, A. Laguna, M. E. Olmos, M. D. Villacampa, Inorg. Chem. Commun., 3, 163 (2000).

29. M. C. Blanco, E. J. Fernández, P.G. Jones, A. Laguna, J. M. López-deLuzuriaga, M. E. Olmos, Angew. Chem. Int. Ed. Engl., 37, 3042 (1998). 
30. M. C. Blanco, E. J. Fernández, J. M. López-de-Luzuriaga, M. E. Olmos, O. Crespo, M. C. Gimeno, A. Laguna, P. G. Jones, Chem. Eur. J., 6, 4116 (2000).

31. M. C. Blanco, E. J. Fernández, M. E. Olmos, O. Crespo, A. Laguna, P. G. Jones, Organometallics, 21, 2426 (2002).

32. A. Bayler, A. Schier, G.A. Bowmaker, H. Schmidbaur, J. Am. Chem. Soc., 118, 7006 (1996).

33. G. A. Carriedo, V. Riera, M. L. Rodríguez, P. G. Jones, J. Lautner, J. Chem. Soc., Dalton Trans., 639 (1989).

34. a) D. Braga, F. Grepioni, F. S. Livotto, M. D. Vargas, J. Organomet Chem., 391, C28 (1990). b) F. S. Livotto, M. D. Vargas, D. Braga, F. Grepioni, J. Chem. Soc., Dalton Trans., 577 (1992).

35. a) R. Bender, P. Braunstein, A. Dedieu, Y. Dusausoy, Angew. Chem. Int Ed. Engl., 28, 923 (1989). b) R. Bender, S.-E. Bouaoud, P. Braunstein, Y. Dusausoy, N. Merabet, J. Raya, D. Rouag, J. Chem. Soc., Dalton. Trans., 735 (1999).

36. H. Schmidbaur, G. Weidenhiller, O. Steigelmann, Angew. Chem. Int. Ed. Engl., 30, 433 (1991).

37. H. Schmidbaur, E. Zeller, G. Weidenhiller, O. Steigelmann, H. Beruda, Inorg. Chem., 31, 2371 (1992).

38. E. Zeller, H. Beruda, J. Riede, H. Schmidbaur, Inorg. Chem., 32, 3068 (1993).

39. http://www.webelements.com
40. L. Weber, U. Lassahn, H.-G. Stammler, B. Neumann, K. Karaghiosoff, Eur. J. Inorg. Chem., 3272 (2002).

41. M. C. Blanco, E. J. Fernández, M. E. Olmos, J. Pérez, O. Crespo, A. Laguna, P. G. Jones, Organometallics, 23, 4373 (2004)

42. a) H.-J. Haupt, M. Schwefer, H. Egold, U. Flörke, Inorg. Chem., 34, 5461 (1995). b) H.-J. Haupt, M. Schwefer, U. Flörke, Inorg. Chem., 34, 292 (1995).

43. H.-J. Haupt, M. Schwefer, U. Flörke, Z. anorg. allg. Chem., 621, 1098 (1995).

44. B. Assmann, H. Schmidbaur, Chem. Ber, 130, 217 (1997).

45. H. Schmidbaur, E. Zeller, J. Ohshita, Inorg. Chem., 32, 4524 (1993).

46. M. C. Blanco, E. J. Fernández, M. E. Olmos, J. Pérez, A. Laguna, Chem. Eur. J., 12, 3379 (2006).

47. a) E. Zeller, H. Beruda, H. Schmidbaur, Chem. Ber, 126, 2033 (1993). b) H. Schmidbaur, Pure Appl. Chem., 65, 691 (1993). c) E. Zeller, H. Schmidbaur, J. Chem. Soc., Chem. Commun., 69 (1993).

48. H. Beruda, E. Zeller, H. Schmidbaur, Chem. Ber, 126, 2037 (1993).

49. D. S. Bohle, G. R. Clarck, C. E. F. Rickard, W. R. Roper, J. Organomet. Chem., 393, 243 (1990).

50. M. T. Bautista, P. S. White, C. K. Schauer, J. Am. Chem. Soc., 116, 2143 (1994).

51. U. Vogel, P. Sekar, R. Ahlrichs, U. Huniar, M. Scheer, Eur. J. Inorg. Chem., 1518 (2003). 